\title{
Influence of Organobentonite Structure on Toluene Adsorption from Water Solution
}

\author{
Nuria Vidal*, Cristina Volzone* \\ Centro de Tecnología de Recursos Minerales y Cerámica-CETMIC, CICPBA-CCT CONICET La Plata. \\ C.C. 49, Cno. Centenario y 506, 1897, M.B. Gonnet, Buenos Aires, Argentina
}

Received: September 15, 2011; Revised: June 22, 2012

\begin{abstract}
Due to increase water pollution by organic compound derived from hydrocarbons such as toluene, several alternative technologies for remediation of polluted water have been originated. In this work natural bentonites were modified with cetyltrimethylammonium $\left(\mathrm{CTMA}^{+}\right)$for obtaining organophilic bentonites. The obtained CTMA-bentonites would be suitable for use as adsorbents of toluene present in water. The influence of structural characteristics of CTMA-bentonites on their adsorption capacity was studied. It was shown that adsorption of toluene depended on homogeneous interlayer space associated with arrangements of $\mathrm{CTMA}^{+}$paraffin-monolayer and bilayer models, accompanied by a high degree ordering of the carbon chain of organic cation in both arrangements. However, packing density would not have an evident influence on the retention capacity of these materials. The solids obtained were characterized by chemical analysis, X-ray diffractions and infrared spectroscopy. Toluene adsorption was measured by UV-visible spectrophotometer. Adsorption capacity was studied by determining adsorption isotherms and adsorption coefficient calculation. The adsorption isotherms were straight-line indicating a partition phenomenon of toluene between the aqueous and organic phase present in organophilic bentonites.
\end{abstract}

Keywords: bentonites, CTMA-bentonites, toluene, adsorption

\section{Introduction}

Contaminated water, soil and air by various chemicals (arsenic, lead, zinc, chromium, copper, benzene, toluene, naphthalene, phenols, polychlorinated biphenyls, organochlorine dyes, etc.) have generated international preoccupation. Several authors have characterized and developed efficient materials to retain these pollutants ${ }^{1-3}$. Aromatic compounds, in general, have certain toxicity and are considered possible carcinogenic and dangerous in very small concentrations. Among the most notable pollutants, related almost directly to the chemical and petrochemical industry, are organic non-ionic (NOC's) such as toluene, which also is a constituent of the BTEX group (benzene, toluene, ethylbenzene and xylenes) ${ }^{4}$. Toluene concentrations in industrial wastewaters can reach values around $800 \mathrm{mg} . \mathrm{L}^{-1}$, depending on the manufacture type ${ }^{5}$. Some processes available to retain toluene of polluted water, include: biodegradation with bacteria ${ }^{6,7}$, combined (ceramic biofilters presence of fungi $)^{8}$, activated carbon ${ }^{9-11}$, etc. Although these materials are used for adsorbing different concentrations of toluene present in water, its widespread use is limited by its high cost of manufacturing ${ }^{12}$. Ideal natural materials used as a filter or barriers to adsorb a wide variety of pollutants are the bentonite clays ${ }^{13-15}$. Bentonites have low operation cost and are also present as deposits in most continents of the world, making them economical materials. These rocks are generally composed of montmorillonite type and also contain small amounts of other minerals,

*e-mail: ncv86@hotmail.com; volzcris@ netverk.com.ar usually quartz, feldspar, volcanic glass, gypsum, pyrite and organic matter ${ }^{16}$.

Montmorillonite is a hydrated aluminum silicate, its layered structure belonging to the 2:1 type clay minerals, whose basic structure is constituted by an aluminum octahedral layer between two layers of tetrahedral silica $(\mathrm{T}-\mathrm{O}-\mathrm{T})^{17}$. In both tetrahedral and octahedral layers of cations $\mathrm{Si}^{+4}$ and $\mathrm{Al}^{+3}$ respectively, isomorphic replacement can take place generating negative charges in the mineral structure.

The charges are compensated by exchangeable cations such as $\mathrm{Na}^{+}, \mathrm{K}^{+}, \mathrm{Ca}^{++}, \mathrm{Mg}^{++}$, etc. The clay minerals are hydrophilic in nature and can be transformed in organophilic, for example, after exchanging natural cations by organic cations such as those derived from quaternary ammonium salts. In this way, the solids are generally named organoclays and these materials are capable of retaining non-polar organic compounds present in contaminated waters $^{18-47}$. Cetiltrimetilamonio (CTMA)-bentonites as adsorbents for organic pollutants present in water were studied by different authors through the years ${ }^{48-51}$.

Jaynes and Boyd ${ }^{22}$ retained toluene from CTMA-clays and found that the higher adsorption capacity was associated with large interlaminar spacing of the clay mineral in the presence of long carbon chain of the CTMA ${ }^{+}$. For Jaynes and Vance ${ }^{25}$, toluene present in water was efficiently adsorbed by organo-clays prepared from montmorillonite modified with organic cations of long alkyl chain as the $\mathrm{CTMA}^{+}$. They observed that the adsorption was governed by the arrangement adopted by the organic 
cation associated with important interlaminar spacing (e.g. paraffin-type). Cetyltrimethylammonium $\left(\mathrm{CTMA}^{+}\right)$ generates an organophilic phase partition in the interlayer space of the montmorillonite constituent of bentonite ${ }^{52-54}$.

Sharmasarkar et al..$^{31}$ evaluated the adsorption of toluene and other hydrocarbons by some organo-montmorillonite and also evaluated the adsorptive capacity of these materials in relation to type of organic cation, molecular weight and interlayer spacing in the organo-clays.

Loess soils with high contents of organic carbon provided by the $\mathrm{CTMA}^{+}$cation and high cation exchange capacity were much more efficient than non-modified soils to sorbent toluene, a NOC ${ }^{34}$. According to Ramos Vianna et al. ${ }^{42}$ Brazilian purified sodium bentonite in different amounts was used to prepare CTMA - organoclays and they observed that bentonite in different amounts ( $1 \%$ and $4 \%$ ) treated with CTMA equivalent to the CEC of the original clay, showed higher adsorptive properties as tested by using toluene as the reference adsorbate. Nevertheless, the studies of adsorption of toluene in water referred to arrangement and degree of ordering chain alkyl of the cation organic in this CTMA-bentonite type are scarce. In this work adsorption isotherm of toluene by CTMA-bentonite was obtained and the influence of arrangement and ordering of carbon chain with toluene retention by bentonite, solid that can be used as potential adsorbents for toluene and environmental applications, was analysed.

\section{Material and Methods}

Selected bentonites for this study were two Argentines ( $\mathrm{Ja}$ and DL) and two from the USA (B1 and B2). The bentonites contain montmorillonite (smectite- type) as the main mineralogical component with variable amounts of impurities (Table 2). Dried bentonitic clay samples were crushed to pass a sieve M:200 (<74 $\mu \mathrm{m})$. The cation exchange capacity (CEC) of each bentonite was 0.98 meq.g ${ }^{-1}, 1.0$ meq.g $\mathrm{g}^{-1}, 1.10$ meq.g ${ }^{-1}$ and 0.97 meq. $\mathrm{g}^{-1}$ for Ja, DL, B1 and B2 samples, respectively. The CEC was determined by using $2 \mathrm{~N}$ ammonium acetate at $\mathrm{pH}=8$.

The $\mathrm{CTMA}^{+}$, Table 1 , is a monovalent cation of cetyltrimthylammonium, containing nineteen carbon atoms. It was selected in this work for preparing organo-bentonites.

Different CTMA-bentonites were prepared adding cetiltrimethylammonium chloride equal to CEC. An amount of $2 \mathrm{~g}$ of bentonite per $100 \mathrm{~mL}$ aqueous solutions of CTMA chloride salt was contacted for 24 hours. The solids were washed with distilled water to remove excess salt, separated, and dried at $60{ }^{\circ} \mathrm{C}$. CTMA-bentonites samples were crushed to pass a sieve M:200 (<74 $\mu \mathrm{m})$ and stabilized at a relative humidity of $55 \%(\mathrm{RH})$ before characterization. The CTMA-bentonites were named JaC, B1C, B2C and DLC.

Organic carbon (OC) contents in the samples were determined by the Solid Simple Module SSM-5000A for TOC-5000(A)/5050(A) Total Organic Carbon Analyzer, Shimadzu.

Chemical analyses of the bentonites were obtained using Inductively Coupled Plasma (ICP) and were performed on crushed sample to pass a sieve M: $200(<74 \mu \mathrm{m})$.

The X-ray diffraction (XRD) of the samples were obtained by using a Philips 3020 Goniometer equipment with PW 3710 Controller, $\mathrm{Cu} \mathrm{K} \alpha$ radiation $(\lambda=1.5405 \AA$ ), and Ni filter at $40 \mathrm{kV}$ and $20 \mathrm{~mA}$. The patterns were obtained by scanning at $1^{\circ}(2 \theta) / \mathrm{min}$ between 2.2 and $70^{\circ}(2 \theta)$. Quantitative identification of crystalline phase was carried out by Rietveld method.

Fourier transform infrared spectroscopy (FTIR) spectra using $\mathrm{KBr}$ pressed disk technique were conducted on Spectrum One Perkin Elmer equipment. The spectra were collected for each measurement over the spectral range of 400-4000 $\mathrm{cm}^{-1}$.

Toluene concentrations in water analyzed were in the range of 50 to $1000 \mathrm{mg} . \mathrm{L}^{-1}$. Batch sorption experiments of toluene by CTMA-bentonites were made by weighing $200 \mathrm{mg}$ organo-bentonite sample into $10 \mathrm{~mL}$ of aqueous solution of toluene. Toluene uptake by organo-bentonite was calculated from the difference between the quantity of toluene added and the quantity remaining in the equilibrium solution after 24 hours of contact. The amount of toluene was determined by measuring the absorbance at $261 \mathrm{~nm}$ in a Hewlett Packard 8435 spectrophotometer. All measurements were done in duplicate. Blank experiments (without CTMA-bentonite) were measured each time to determine possible loss in the solution of toluene by evaporation.

\section{Results and Discussion}

Applying the Rietveld method to the analysis by X-ray diffraction, in the Table 2, was observed that the bentonites were montmorillonite-rich samples (major component over 87\%)

Table 1. Characteristics of $\mathrm{CTMA}^{+}$cation.

\begin{tabular}{ccc}
\hline Name & Abbreviation & Dimensions and structure \\
\hline Cetyltrimethylammonium cation & CTMA $^{+}$ & Side: $\mathbf{a}=25.3 \AA ; \mathbf{b}=5.1 \AA ; \mathbf{c}=4.6 \AA$ \\
Up: $\mathbf{a}=25.3 \AA ; \mathbf{b}^{\prime}=6.7 \AA ; \mathbf{c}^{\prime}=4.1 \AA$
\end{tabular}

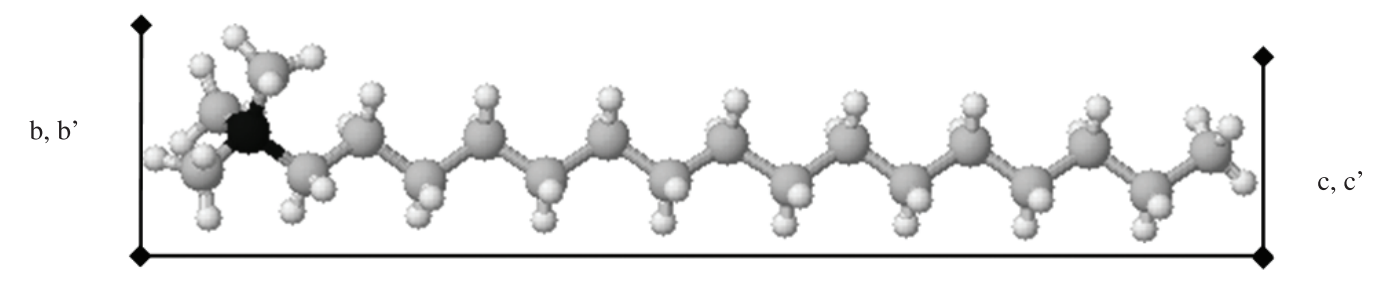


with small, but variable, amount of quartz, calcium feldspar, sodium feldspar y cristobalite.

According to mineralogical and chemical analyses (Table 3 ) of the clays, the samples are typical of bentonites ${ }^{16,52,55-57}$. Bentonites, mainly composed of smectites, can be grouped in Cheto-type if the amount of magnesium expressed as oxide in the range of 5 to $6 \%$ and Wyoming-type if the amount of iron as oxide $\left(\mathrm{Fe}_{2} \mathrm{O}_{3}\right)$ in the range of 3 to $5 \%$. For the bentonites selected content of magnesium expressed as oxide $(\mathrm{MgO})$ is higher for samples B1 and $\mathrm{Ja}$ (6.91 and 6.65\%), compared with samples B2 and DL (2.78 and 3.33\%). However, these last two bentonites have a higher content of iron expressed as oxide $\left(\mathrm{Fe}_{2} \mathrm{O}_{3}=4.17\right.$ and $\left.4.69 \%\right)$ compared with $\mathrm{B} 1$ and Ja.

The adsorption isotherms of toluene in water onto organic bentonites are shown in Figure 1. CTMA-bentonites showed linear adsorption isotherms in all the range of the study, similar to Class- C isotherm proposed by Giles et al. ${ }^{59}$.

A linear model was used for a quantitative evaluation of adsorption, according to the following equation: $X / M=K_{d} \mathrm{C}_{\mathrm{e}}$, where $\mathrm{X}=$ mass of toluene removed from solution (mmol), $\mathrm{M}=$ mass of adsorbent $(\mathrm{kg}), \mathrm{Ce}=$ solution equilibrium concentration (mmol. $\left.\mathrm{L}^{-1}\right)$ and $K d=$ adsorption coefficient, linear partition or distribution $\left(\mathrm{L}^{\mathrm{kg}} \mathrm{kg}^{-1}\right)$ of toluene between the aqueous phase and CTMA-bentonite. The adsorption coefficient $K_{d}$ for each series of CTMA-bentonite was calculated from the equation referred, Table 4. Linear correlation coefficient was $r \geq 0.97$ for all adsorption isotherms. Linearity of the isotherms would be related to behavior known as hydrophobic partitioning process, which occurs mainly between organic contaminants with scarce o non-polarity and non-polar parts of a large molecule ${ }^{60,61}$. In this work, the partitioning process would be between hydrophobic parts of the organics cations in interlayer spacing and toluene in water. Table 4 shows the partition coefficients $\left(K_{d}\right)$ of adsorption toluene by the organobentonites. The sample $\mathrm{JaC}$ gave the highest $K_{d}$ value $258 \mathrm{~L} . \mathrm{kg}^{-1}$, while the lowest $K_{d}$ value of adsorption of toluene 140 L. $\mathrm{kg}^{-1}$ was obtained for B2C.

Normalized $K_{d}$ value $\left({\mathrm{L} . \mathrm{kg}^{-1}}^{-1}\right.$ by organic content present in each organic bentonite, arise organic content corrected coefficient, $K_{o m}$ (L.kg ${ }^{-1}$ of carbon) (Table 4) ${ }^{62}$, calculated according to the Equation 1:

$$
K_{\text {om }}=\left(K_{d} / O C \times f_{O C}\right) 1000, \text { where } f_{O C}=\frac{w_{C T M A^{+}}}{w_{C}}
$$

where $O C$ is the organic carbon (mgC. $\mathrm{g}^{-1}$ sample); $W_{\text {CTMA+ }}$ weight of $\mathrm{CTMA}^{+}$and $W_{C}$ was the weight of carbon in $\mathrm{CTMA}^{+}$. It was observed that the adsorption capacity, $K_{d}$, of each series CTMA-bentonites increased with increasing organic content, associated with the simultaneous increase in the $K_{\text {om }}$ (Table 4, Figure 2). Jaynes and Boyd ${ }^{22}$, Jaynes and Vance ${ }^{25}$, Sharmasarkar et al. ${ }^{31}$; Chen et al. ${ }^{34}$; Ramos Vianna et al. ${ }^{42}$, found similar $O C, K_{d}$ and $K_{o m}$ values for smectites montmorillonite-type modified with added amounts of $\mathrm{CTMA}^{+}$equal to those of this work (Table 4).

To evaluate the apparent affinity of toluene for remaining in the organic bentonite or in aqueous phase, it was compared the values obtained for organic content corrected coefficient $\left(K_{o m}\right)$ with octanol coefficient $\left(K_{o w}\right)$ of toluene $\left(489.8 \mathrm{~L} . \mathrm{kg}^{-1}\right)^{63}$, from the following equation: $\log$ $K_{o m}-\log K_{o w}$. If the values obtained from this difference are positive, the affinity of toluene is for solid organic phase and if the values are negative, toluene remains in solution $^{22,42}$. The $\log K_{o m}-\log K_{o w}$ values were positive for all CTMA-bentonites prepared in this paper. The $\mathrm{JaC}$ and B1C samples presented values similar to slightly higher than those expounded by Jaynes and Vance ${ }^{25}$ for SAz-HDTMA used to retain toluene in water, Table 4. For samples DLC and $\mathrm{B} 2 \mathrm{C}$ these values were higher than for Wyoming-type bentonites modified with $\mathrm{CTMA}^{+}$presented by Jaynes and Vance ${ }^{25}$; Sharmasarkar et al. ${ }^{31}$; Ramos Vianna et al. ${ }^{42}$ (Table 4). Based on the results of Table 4, the order of $\log$ $K_{o m}-\log K_{o w}$ for toluene was JaC > DLC > B1C > B2C.

The structure of bentonite clays modified with the $\mathrm{CTMA}^{+}$cation was studied by XDR and FTIR.

Figure 3 shows $\mathrm{X}$ - ray diffraction of natural bentonites (B1, Ja, B2 and DL) containing mainly montmorillonite (as smectite-type); and prepared CTMA-bentonites. It was observed that the interlayer spacing, $d(001)$, of montmorillonite changed in a range of $18.4 \AA$ to $23.9 \AA$ when $\mathrm{CTMA}^{+}$was added in equivalent to the exchange capacity. The change in spacing values of the bentonites B2, DL and

Table 2. Percentage of each mineral phase in selected bentonites.

\begin{tabular}{lcccc}
\hline Mineralogical phase & B1 $(\boldsymbol{\%})$ & Ja $(\boldsymbol{\%})$ & B2 (\%) & DL (\%) \\
\hline Montmorillonite & 96 & 94 & 87 & 92 \\
Quartz & 1 & 1 & 9 & 3 \\
Calcium Feldspar & - & - & - & - \\
Sodium Feldspar & - & 4 & - & 4 \\
Cristobalite & 3 & 1 & & 1 \\
\hline
\end{tabular}

Table 3. Chemical composition (\%) of selected bentonite in dry base.

\begin{tabular}{ccccccccc}
\hline Samples & $\mathbf{S i O}_{\mathbf{2}}(\boldsymbol{\%})$ & $\mathbf{T i O}_{\mathbf{2}}(\boldsymbol{\%})$ & $\mathbf{A l}_{\mathbf{2}} \mathbf{O}_{\mathbf{3}}(\boldsymbol{\%})$ & $\mathbf{F e}_{\mathbf{2}} \mathbf{O}_{\mathbf{3}}(\boldsymbol{\%})$ & $\mathbf{M g O}(\boldsymbol{\%})$ & $\mathbf{C a O}(\boldsymbol{\%})$ & $\mathbf{N a}_{\mathbf{2}} \mathbf{O}(\boldsymbol{\%})$ & $\mathbf{K}_{\mathbf{2}} \mathbf{O}(\%)$ \\
\hline $\mathbf{B 1}$ & 67.37 & 0.25 & 19.99 & 1.74 & 6.91 & 3.24 & 0.10 & 0.21 \\
$\mathbf{J a}$ & 66.42 & 0.28 & 19.31 & 1.66 & 6.65 & 1.61 & 3.22 & 0.75 \\
$\mathbf{B 2}$ & 68.12 & 0.12 & 20.57 & 4.17 & 2.78 & 1.91 & 1.63 & 0.59 \\
$\mathbf{D L}$ & 66.94 & 0.19 & 20.77 & 4.69 & 3.33 & 0.93 & 2.67 & 0.31 \\
\hline
\end{tabular}


$\mathrm{Ja}, \mathrm{B} 1$ are attributed to replacement of interlayer inorganic cations with organic $\mathrm{CTMA}^{+}$cation. Similar spaces were reported by Lee and $\mathrm{Kim}^{64}$; Volzone et al. ${ }^{65}$; Zhu et al. ${ }^{62}$; Vidal and Volzone ${ }^{45}$ for the treatment of bentonite clays with $\mathrm{CTMA}^{+}$.

According to different models proposed by Lagaly et al. ${ }^{66}$; Vaia et al. ${ }^{67}$; Zhu et al. ${ }^{68,69}$; Bergaya et al. ${ }^{70}$; Zhu et al. ${ }^{71}$; Xu and $\mathrm{Zhu}^{72}$ the arrangement of an organic cation of long carbon chain, for example $\mathrm{CTMA}^{+}$, with respect to the sheet of clay mineral would be located in monolayer when interlayer spacing are between $14.8 \AA$ to15.0 $\AA$, in two successive layers (bilayer) when recorded interlayer spacing values between $17.8 \AA$ to $18.8 \AA$; and pseudotrilayer if $d(001)$ values are between $19.5 \AA$ to $21 \AA^{39,73}$. If the carbon chain is inclined a certain angle $\alpha$ or near perpendicular to the sheet mineral clay, this arrangement is called paraffin-type monolayer $(22.3 \AA$ a $30 \AA)$ and paraffin-type bilayer with basal spacing $>30 \AA$ ( $\operatorname{sen} \alpha=$ interlayer spacing/ length of $\mathrm{CTMA}^{+}, 25.3 \AA$ ).

$\mathrm{B} 2$ and DL bentonites (Wyoming-type) increases the interlayer spacing values of $14.4 \AA$ and $14.2 \AA$ to $18.5 \AA$ and $18.4 \AA$, respectively, to be modified with an amount of

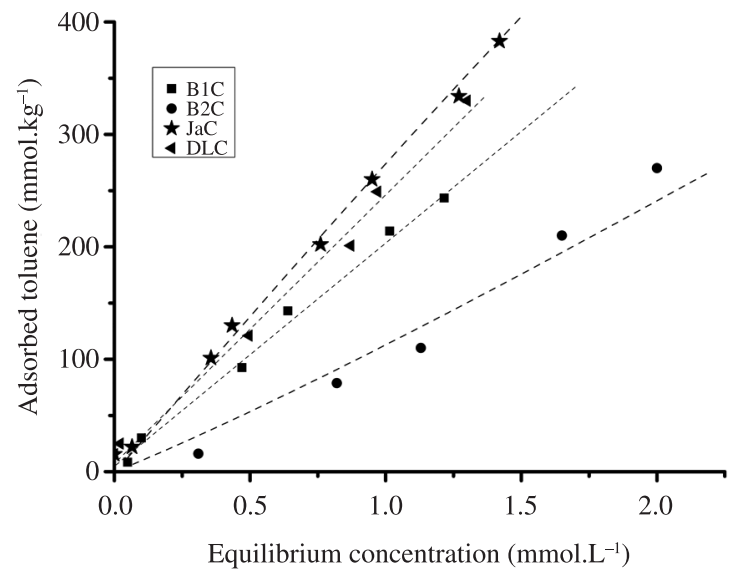

Figure 1. Sorption isotherms of toluene on the CTMA-bentonites.
$\mathrm{CTMA}^{+}$equivalent to $\mathrm{CEC}$. In this case the organic cation adopts a bilayer arrangement with respect to the sheet of clay. According to Zhu et al. ${ }^{71}$ and $\mathrm{Xu}$ and $\mathrm{Boyd}^{74}$, in this type of clay minerals the $\mathrm{CTMA}^{+}$cation never exceed beyond pseudotrilaminar arrangement, by having a low surface charge density generated by the type of isomorphic substitution in the octahedral sheet.

Cheto-type bentonites, B1 and Ja, showed a different behavior to $\mathrm{B} 2$ and DL with modification by $\mathrm{CTMA}^{+}$. The $d(001)$ values for $\mathrm{JaC}$ was $23.9 \AA$ and for sample $\mathrm{B} 1 \mathrm{C}$, coexisting two simultaneously interlayers values $22.8 \AA$ and 15.6 A. Paraffin-monolayer arrangement would be represented in the sample $\mathrm{JaC}$ and with $72 \%$ in the sample B1C. The $28 \%$ of sample B1C may adopt a transition conformation between monolayer and bilayer of carbon tail of organic cation ${ }^{71}$. Both percentages were determined by deconvolution of reflection 001 (Figure 3, dotted line). The heterogeneous interlayer arrangement indicate that $\mathrm{CTMA}^{+}$was distributed differently between the sheets of each clay and such situations only present in Cheto-type montmorillonite ${ }^{64,75,76}$.

For FTIR characterization, there aren't characteristic bands of montmorillonite in the selected spectral region between 3100 and $2700 \mathrm{~cm}^{-1}$, but they are shown for comparison. For CTMA-bentonites, characteristic bands of cation organic $\mathrm{CTMA}^{+}$are localized at $3020 \mathrm{~cm}^{-1}$, assigned to the symmetric stretching mode of the trimethylammonium headgroup $\mathrm{CH}_{3}-\mathrm{N}$ while the bands $2918 \mathrm{~cm}^{-1}$ and $2849 \mathrm{~cm}^{-1}$ are typical asymmetrical and symmetrical modes of bond $\mathrm{C}-\mathrm{H}$ methylene asymmetric and symmetric, respectively (concerning CTMACL solid) ${ }^{77}$. The wavenumber of $\mathrm{C}-\mathrm{H}$ methylene stretching absorption bands of $\mathrm{CTMA}^{+}$cation are extremely sensitive to the degree of ordering adopting carbon chain in each conformation ${ }^{78-81}$. When the chains are highly ordered (all trans) and with high packing density, these absorption bands are close to the wavenumber of the pure CTMACL solid. Nevertheless, He et al. ${ }^{78}$ showed that the asymmetric $\mathrm{C}-\mathrm{H}$ methylene stretching absorption mode is more sensitive to the carbon chain conformation than

Table 4. Distribution coefficients $\left(K_{d}\right)$, coefficient normalized to organic matter $\left(\mathrm{K}_{\mathrm{om}}\right)$ for CTMA-bentonites in this paper and different authors.

\begin{tabular}{|c|c|c|c|c|c|}
\hline Adsorbent & $K_{d}\left(\mathbf{L} \cdot \mathbf{k g}^{-1}\right)$ & $\begin{array}{c}\text { Organic Carbon } \\
\left(\text { OC) }\left(\mathrm{mgC}^{-g^{-1}}\right)\right.\end{array}$ & $K_{o m}\left(\mathbf{L} \cdot \mathbf{k g}^{-1}\right)$ & $\log K_{o m}-\log K_{o w}$ & References \\
\hline $\mathrm{JaC}$ & 258 & 183 & 1130 & 0.363 & \multirow{4}{*}{ This paper } \\
\hline DLC & 237 & 181 & 1049 & 0.331 & \\
\hline $\mathrm{B} 1 \mathrm{C}$ & 196 & 164 & 957 & 0.291 & \\
\hline B2C & 140 & 174 & 645 & 0.120 & \\
\hline SWy-CTMA & 74 & 174.6 & 338.84 & -0.16 & \multirow{2}{*}{ Jaynes and Boyd ${ }^{22}$} \\
\hline Saz-CTMA & 319 & 230 & 1122 & 0.36 & \\
\hline SWy-CTMA & 114 & 167 & 548.04 & 0.05 & \multirow{2}{*}{ Jaynes and Vance ${ }^{25}$} \\
\hline Saz-CTMA & 317 & 239 & 1064.84 & 0.34 & \\
\hline SWy-CTMA & 79.43 & 168 & 378.67 & -0.11 & Sharmasarkar et al. ${ }^{31}$ \\
\hline Loess Soil - CTMA & 11.9 & 8.34 & nd & nd & Chen et al. ${ }^{34}$ \\
\hline Na-Smectite-CTMA $(1 \%, 100)$ & 140 & 156 & 721.57 & 0.17 & \multirow{2}{*}{ Ramos Vianna et al. ${ }^{42}$} \\
\hline Na-Smectite-CTMA $(4 \%, 100)$ & 131 & 162 & 649.60 & 0.12 & \\
\hline
\end{tabular}

* $\log \mathrm{K}_{\mathrm{ow}}$ toluene: 2.69 
the symmetric $\mathrm{C}-\mathrm{H}$ methylene stretching absorption mode is. If the band of stretching asymmetrical $\mathrm{C}-\mathrm{H}$ methylene is shifted to a higher wavenumber and widens, that would indicate a tendency to disorder (gauche) of the amine chain of $\mathrm{CTMA}^{+}$in the conformation adopted ${ }^{67,81,82}$. In the selected CTMA-bentonites the degree of ordering increased from the sample B2C $\left(2925.6 \mathrm{~cm}^{-1}\right)$, followed by DLC and B1C, these last two samples being similar $\left(2922 \mathrm{~cm}^{-1}\right.$ and $2921.5 \mathrm{~cm}^{-1}$, respectively) because their wavenumber only show a slight difference of less than $1 \mathrm{~cm}^{-1[83]}$; to the greatest ordering corresponding to sample $\mathrm{JaC}\left(2919.5 \mathrm{~cm}^{-1}\right)$.

It has also been observed that the absorption band at $3020 \mathrm{~cm}^{-1}$ showed a more notable intensity in the samples $\mathrm{JaC}$ and DLC compared to samples B1C and B2C. The presence of this band would be related to a higher ordering of the large carbon chain ${ }^{80}$. Figure $4 \mathrm{~b}$ showed doublet for the band associated with scissoring (1490 y $\left.1490 \mathrm{~cm}^{-1}\right)$

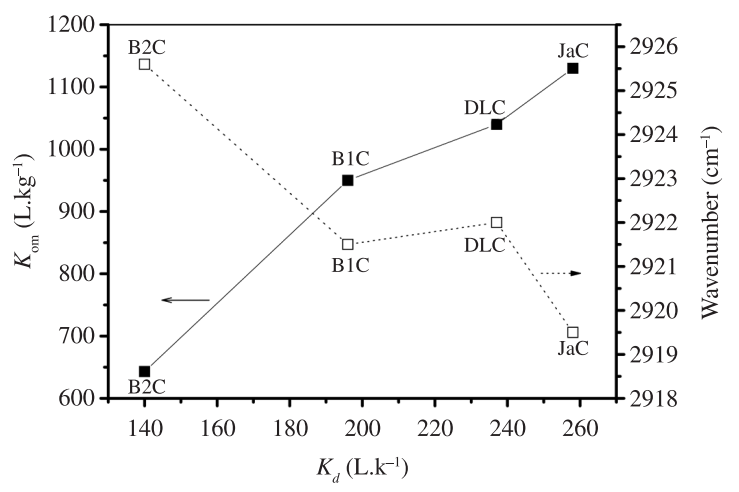

Figure 2. $\mathrm{K}_{o m}$ and wavenumber of stretching asymmetric vibration modes of C-H metilene as a function of $K_{d}$.
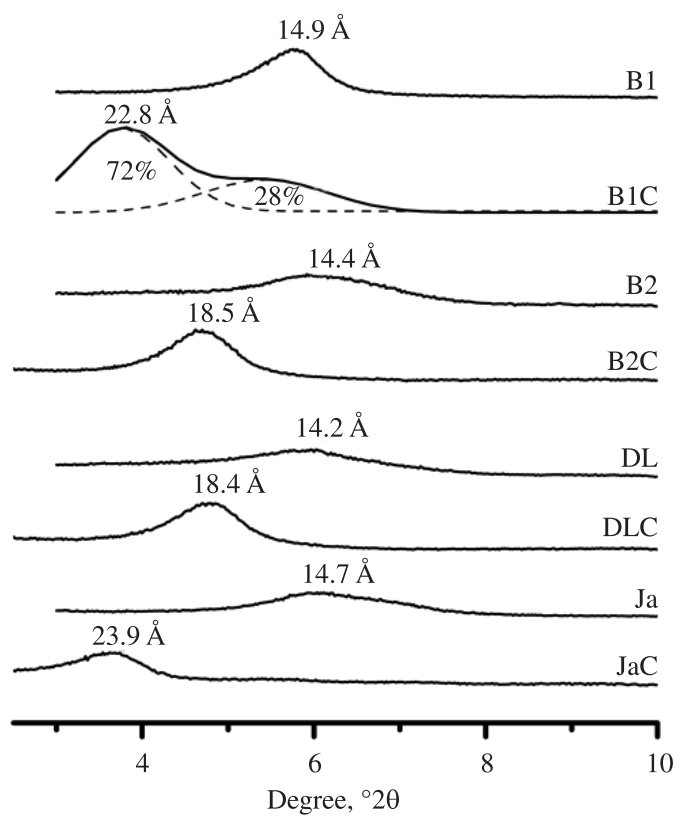

Figure 3. X-ray diffraction and basal spacing of bentonites before and after cetyltrimethylammonium exchange. Deconvolution in dotted line. and rocking at $710 \mathrm{~cm}^{-1}$ vibration modes for bond $\mathrm{C}-\mathrm{H}$ methylene. Presence of the band at $710 \mathrm{~cm}^{-1}$ and doublet of scissoring modes suggest the tendency to ordering that would take the carbon chain and an increase in the intensity of both bands is associated with higher carbon content $^{78}$. It has been observed that these bands are present in all CTMA -bentonite, and its intensity is greater in the DLC and $\mathrm{JaC}$ in respect to $\mathrm{B} 1 \mathrm{C}$ and $\mathrm{B} 2 \mathrm{C}$ organobentonites

Figure $4 \mathrm{a}$ includes the IR spectrum of organic bentonite after retain toluene (B1Ct, B2Ct, JaCt, DLCt) in dotted line. Characteristic bands of toluene ranging from 3100 to $2700 \mathrm{~cm}^{-1}$, correspond to both stretching symmetric $\left(2960 \mathrm{~cm}^{-1}\right.$ and $2854 \mathrm{~cm}^{-1}$ ) and asymmetric (2925 and $2919 \mathrm{~cm}^{-1}$ ) stretching vibration modes for C-H metal ${ }^{84-89}$ but in general are overlapped by the characteristic bands of the $\mathrm{CTMA}^{+}$cation $^{90}$.

Understanding the factors affecting the adsorption coefficient, $\mathrm{K}_{d}$, for each group of CTMA-bentonite is very important for predicting and optimizing the adsorption capacity of these organic bentonites for retaining toluene present in water.

The hydrophobic environment created in the bentonite clay by the presence of the organic cation of long carbon chain $\left(\mathrm{CTMA}^{+}\right)$showed to be a good environment to retain toluene present in water ${ }^{91}$. The resulting mechanism, that controls the retention of toluene in this medium, was partition into the organic phase created by the organic bentonites (Figure 1). In the calculated $K_{d}$ values for this system, it was observed that they had a direct relationship with increasing organic content of each clay, expressed as $K_{o m}$, Table 4 and Figure 2. However, differences in retention of toluene between each CTMA-bentonite can be attributed to structural differences between them (e.g.: type of arrangement and state of ordering of $\mathrm{CTMA}^{+}$in the interlayer of the clay mineral). According to Jaynes and Boyd ${ }^{22}$; Jaynes and Vance ${ }^{25}$ only the interlayer spacing values, $d(001)$, associated with paraffin-type monolayer arrangement of carbon chain of cation organic, demonstrated to be related to optimal adsorptive capacities of different clay minerals modified with organics to retain benzene, toluene, ethylbenzene, propylbenzene, naphthalene, biphenyls and xylenes.

The high degree of ordering of paraffin- type monolayer arrangement of cation $\mathrm{CTMA}^{+}$of the sample $\mathrm{JaC}$ would be consistent with the highest $K_{d}$ values ( $258 \mathrm{~L} \cdot \mathrm{kg}^{-1}$ ). However, for sample B1C paraffin-type monolayer arrangement represented around $72 \%$ and its $K d$ value $\left(196{\mathrm{~L} . \mathrm{kg}^{-1}}^{-1}\right)$ would be the same percentage (or the same proportion as a percentage) of the value of the coefficient for sample Ja1C. In this way, it could be inferred that transition between monolayer and bilayer arrangement, also found in $\mathrm{B} 1 \mathrm{C}$ which corresponds to $28 \%$ of the 001 reflection, would be attributed as an inactive phase front to retention of toluene in water, causing the retention efficiency to be decreased. Although interlayer spacing value, $d(001)$, and bilayer arrangement are similar between samples DLC and

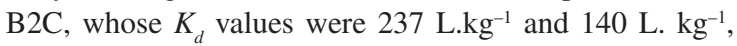
respectively, DLC organic bentonite gave the second highest $K_{d}$ value with respect to the sample JaC. This behavior can be explained due to the degree of ordering 


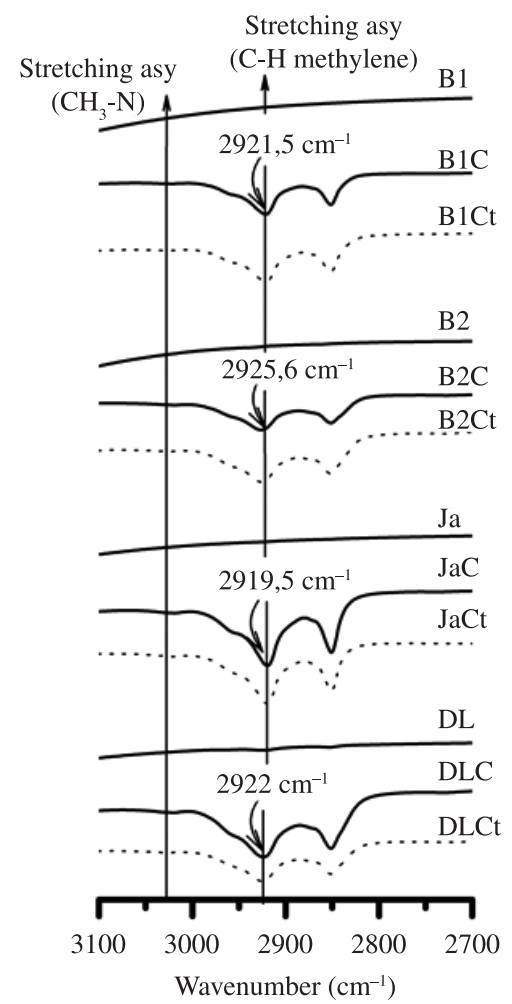

(a)

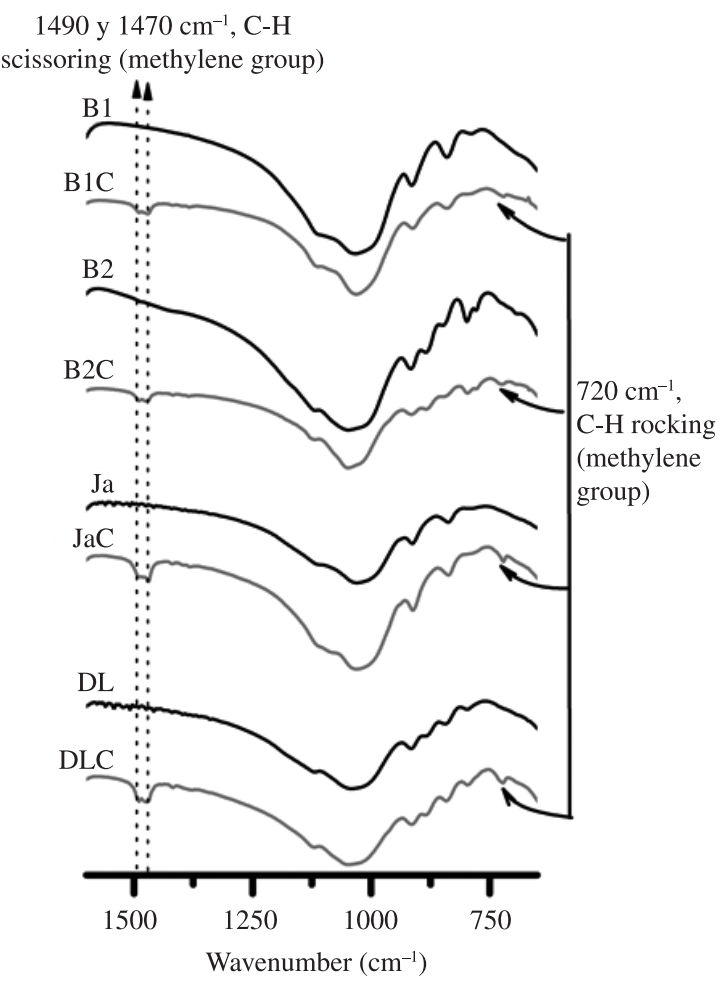

(b)

Figure 4. FTIR patterns: a) bentonites, and CTMA-bentonites with and wothout toluene in the region $3100-2700 \mathrm{~cm}^{-1}$; b) bentonites and CTMA-bentonites in the region $1550-700 \mathrm{~cm}^{-1}$.

that would adopt the $\mathrm{CTMA}^{+}$cation between the sheets of clay mineral in the bilaminar arrangement of both samples.

Some authors have observed that the retention properties of CTMA-clay type depend on the arrangement/ configuration of the organic cation which is controlled by the organic carbon content between layers ${ }^{46,62,72}$. Although, Zhu et al. ${ }^{81}$ observed that $K_{o m}$ value of CTMA-montmorillonite used to adsorb naphthalene in water, gradually increases to a maximum and then decreases sharply when the amount of carbon retained is equivalent to a high ordering and packing density of the tail carbon of $\mathrm{CTMA}^{+}$on the interlayer spacing. In this paper, a correlation between the increase in the degree of ordering that adopts the carbon chain of the $\mathrm{CTMA}^{+}$and increased $K_{d}$ value of different organic bentonite, independent of the arrangement adopted by the organic cation, was observed (Figure 2). That is, the efficiency of adsorption of toluene in water would be favored in those organic bentonites in which the band corresponding to stretching asymmetric vibration modes for bond $\mathrm{C}-\mathrm{H}$ metilene presented wavenumber values until close to that of CTMACL solid. The selected CTMA-bentonites showed that JaC and DLC have higher $K_{o m}$ values compared to samples B1C and B2C, according to a higher ordering of the carbon chain in each arrangement models of the $\mathrm{CTMA}^{+}$between the sheets of clay mineral (Figure 2).

In contrast to that observed by Zhu and Zhu ${ }^{46}$; Zhu et al ${ }^{92}$ the packing density conformation between the alkyl chains would be a factor that would influence little on the retention capacity of each organo-bentonite. Presence of toluene in the samples does not generate changes in the position of the band's associated stretching asymmetric vibration modes of C-H methylene $\left(\sim 2920 \mathrm{~cm}^{-1}\right)$ to the four CTMA-bentonites. This behavior suggests it would not have a high packing density between the carbon chains of $\mathrm{CTMA}^{+}$cations present in the interlayer spacing, at the time of the adsorption of toluene, shown in dotted line in Figure 4a.

Thereby, homogeneous interlayer space associated with arrangements of $\mathrm{CTMA}^{+}$paraffin-monolayer and bilayer models, accompanied by a high order of the carbon chain of organic cation in both arrangements, increase the adsorption capacity of CTMA-bentonite prepared from natural bentonite

\section{Conclusion}

The presence of carbon in the treated bentonite with $\mathrm{CTMA}^{+}$played an important role in the retention of toluene. It was observed that homogeneous spaces corresponding to a paraffin-monolayer or bilayer arrangement, accompanied by a high ordering of the organic cation between the sheets of clay mineral, can optimize the capacity of CTMA-bentonite adsorbent for retaining toluene from water solution. The packing density of cation $\mathrm{CTMA}^{+}$in the interlayer space of the montmorillonite would not have an evident influence on the retention capacity of these materials.

Obtained CTMA-bentonites from natural bentonites with high montmorillonite content, originated an adsorbent 
with potential application to remove varying concentrations of toluene present in contaminated water. The low cost of bentonite due to its abundance in nature, easy development and its modification by a simple physicochemical process with cation $\mathrm{CTMA}^{+}$makes them viable materials for application.

\section{References}

1. Jaber M, Miehé-Brendlé J, Michelin L and Delmotte, L. Heavy Metal Retention by Organoclays: Synthesis, Applications, and Retention Mechanism. Chemistry of Materials. 2005; 17:5275-5281. http://dx.doi.org/10.1021/ cm050754i

2. Carmody O, Frost R, Xi Y and Kokot S. Adsorption of hydrocarbons on organo-clays - Implications for oilspill remediation. Journal of Colloid and Interface Science. 2007; 305:17-24. PMid:17046013. http://dx.doi. org/10.1016/j.jcis.2006.09.032

3. Mohan D and Pittman Junior CU. Arsenic removal from water/ wastewater using adsorbents - A critical review. Journal of Hazardous Materials. 2007; 142:1-53. PMid:17324507. http:// dx.doi.org/10.1016/j.jhazmat.2007.01.006

4. Kieth LH and Telliard WA. ES\&T. Special Report. Priority pollutants. I-a perspective view. Environmental Science and Technology. 1979; 13(4):416-423. http://dx.doi.org/10.1021/ es60152a601

5. Enright AM, Collins G and O'Flaherty V. Low-temperature anaerobic biological treatment of toluene-containing wastewater. Water research. 2007; 41:1465-1472. PMid:17306857. http:// dx.doi.org/10.1016/j.watres.2007.01.005

6. Chin KK, Ong SL, Poh LH and Kway HL. Wastewater treatment with bacterial augmentation. Water Science and Technology, 1996; 33(8):17-22. http://dx.doi.org/10.1016/02731223(96)00256-9

7. Shim H and Yang S-T. BTEX removal from contaminated groundwater by a co-culture of Pseudomonas putida and Pseudomonas fluorescens immobilized in a continuous fibrous-bed bioreactor. Journal of Chemical Technology and Biotechnology. 2002; 77(12):1308-1315. http://dx.doi. org/10.1002/jctb.711

8. Aizpuru A, Dunat B, Christen P, Auria R, García-Peña I and Revah S. Fungal biofiltration of toluene on ceramic rings. Journal of Environmental Engineering. 2005; 131(3):396-402. http://dx.doi.org/10.1061/(ASCE)0733-9372(2005)131:3(396)

9. Farhadian M,DuchesD, VachelardCandLarrocheC.BTXremoval from polluted water through bioleaching processes. Applied biochemistry and biotechnology. 2008; 151(2-3):295-306. PMid:18427740. http://dx.doi.org/10.1007/s12010-008-8189-0

10. Park Y, Ayoko GA and Frost RL. Application of organoclays for the adsorption of recalcitrant organic molecules from aqueous media. Journal of Colloid and Interface Science. 2011; 354:292-305.

11. Altenor S, Carene-Melane B and Gaspard S. Activated Carbons from lignocellulosic waste materials for water treatment: a review. International Journal of Environmental Technology and Management. 2009; 10(3-4):308-326. http://dx.doi. org/10.1504/IJETM.2009.023737

12. Ahmaruzzaman M. Adsorption of phenolic compounds on low-cost adsorbents: A review. Advances in Colloid and Interface Science. 2008; 143:48-67. PMid:18786665. http:// dx.doi.org/10.1016/j.cis.2008.07.002

\section{Acknowledgements}

Financial support of CONICET thankfully acknowledged. The authors also wish to thank Lic. Gastón Guzmán (CIDEPINT) for his collaboration in recording infrared spectra of the samples

13. Bellir K, Bencheikh-Lehocine M, Meniai A-H and Gherbi N. Study of the retention of heavy metals by natural material. Desalination. 2005; 185:111-119. http://dx.doi.org/10.1016/j. desal.2005.03.074

14. Gates WP, Bouazza A and Churchman GJ. Bentonite Clay Keeps Pollutants at Bay Elements. Mineralogical Society of America. 2009; 5(2):105-110.

15. Koutsopoulou E, Papoulis D, Tsolis-Katagas P and Kornaros M. Clay minerals used in sanitary landfills for the retention of organic and inorganic pollutants. Applied Clay Science. 2010; 49:372-382. http://dx.doi.org/10.1016/j. clay.2010.05.004

16. Grim RE and Güven N. Bentoniles-Geology, Mineralogy, Properties, and Uses. Amsterdam: Elsevier; 1978.

17. Wolters F, Lagaly G, Kahr G, Nueesch R and Emmerich K. A Comprehensive Characterization of Dioctahedral Smectites. Clays and Clay Minerals. 2009; 57(1):115-133. http://dx.doi. org/10.1346/CCMN.2009.0570111

18. Lagaly G. Characterization of clays by organic compounds. Clay Minerals, 1981; 16:1-21. http://dx.doi.org/10.1180/ claymin.1981.016.1.01

19. Mortland MM, Shaobai S and Boyd SA. Clay-organic complexes as adsorbents for phenol and chlorophenols. Clays and Clay Minerals. 1986; 34:581-586. http://dx.doi. org/10.1346/CCMN.1986.0340512

20. Lee J-F, Mortland MM, Boyd SA and Chiou CT. Shapeselective adsorption of aromatic molecules from water by tetramethylammonium-smectite. Journal of the Chemical Society, Faraday Transactions. 1989; 1(85):2953-2962.

21. Lee J-F, Mortland M, Chiou CT, Kile DE and Boyd SA. Adsorption of benzene, toluene, and xylene by two tetramethylammonium-smectites having different charge densities. Clays and Clay Minerals. 1990; 38(2):113-120. http://dx.doi.org/10.1346/CCMN.1990.0380201

22. Jaynes WF and Boyd SA. Clay mineral type and organic compound sorption by hexadecyltrimethylammoniumexchanged clays. Soil Science Society of America Journal. 1991; 55:43-48. http://dx.doi.org/10.2136/ sssaj1991.03615995005500010007x

23. Jaynes WF and Boyd SA. Hydrophobicity of siloxane surfaces in smectites as revealed by aromatic hydrocarbon adsorption from water. Clays and Clay Minerals. 1991; 46:10-17.

24. Kukkadapu RK and Boyd SA. Tetramethylphosphonium - and Tetramethylammonium smectites as adsorbents of aromatic and chlorinated hydrocarbons: Effect of water on adsortion effeiciency. Clays and Clay Minerals, 1995; 43(3):318-323. http://dx.doi.org/10.1346/CCMN.1995.0430306

25. Jaynes WF and Vance GE. BTEX Sorption by Organo-Clays: cosorptive enhancement and equivalence of interlayer complex. Soil Science Society of America Journal. 1996; 60:1742-1749. http://dx.doi.org/10.2136/sssaj1996.03615995006000060019x

26. Shen G, Xu S and Boyd SA. Mechanism(s) controlling sorption of neutral organic contaminants by surfactant- 
derived and natural organic matter. Environmental Science \& Technology. 1996; 30:1553-1557. http://dx.doi.org/10.1021/ es9505208

27. Gitipour S, Bowers MT and Bodocsi A. The Use of Modified Bentonite for removal of Aromatic Organics from Contaminated Soil. Journal of Colloid and Interface Science. 1997; 196:191-198. PMid:9792744. http://dx.doi.org/10.1006/jcis.1997.5063

28. Churchman GJ. Modification of bentonite with different polycations for the uptake of aromatic hydrocarbons from water. In: Proceedings of the International workshop of Active Clays; 1998; La Plata. La Plata; 1998. p. 9-19.

29. Lo IM, Lee SC-H and Mak RK-M. Sorption of nonpolar and polar organics on dicetyldimethylammonium-bentonite. Waste Management \& Research. 1998; 2:129-138. http://dx.doi. org/10.1177/0734242X9801600205

30. Jaynes WE and Vance GE. Sorption of benzene, toluene, ethylbenzene, and xylene (BTEX) compounds by hectorite clays exchanged with aromatic organic cations. Clays and Clay Minerals, 1999; 47(3):358-365. http://dx.doi.org/10.1346/ CCMN.1999.0470312

31. Sharmasarkar S, Jaynes W and Vance GF. BTEX sorption by montmorillonite organo-clays: TMPA, ADAM, HDTMA ${ }^{+}$. Water, Air, and Soil Pollution. 2000; 119:257-273. http://dx.doi. org/10.1023/A:1005167524630

32. Volzone C, Rinaldi JO and Ortiga J. Utilización de organo - bentonitas para la retención de toleno en agua. In: Anales de las VI Jornadas Argentinas de Tratamiento de Minerales; 2000; Salta, Argentina. Salta; 2000. v. 1, p. 255-259.

33. Koh S-M and Dixon JB. Preparation and application of organominerals as sorbents of phenol, benzene and toluene. Applied Clay Science. 2001; 18:111-122. http://dx.doi.org/10.1016/ S0169-1317(00)00040-5

34. Chen H, Yang R, Zhu K, Zhou W and Jiang M. Attenuating toluene mobility in loess soil modified with anion-cation surfactants. Journal of Hazardous Materials. 2002; B94:191-201. http:// dx.doi.org/10.1016/S0304-3894(02)00083-3

35. ShenY-H. Renoval of phenol from water by adsorption-flocculation using organobentonite. Water Research. 2002; 36:1107-1114. http://dx.doi.org/10.1016/S0043-1354(01)00324-4

36. Beall GW. The use of organo-clays in water treatment. Applied Clay Science. 2003; 24:11-20. http://dx.doi.org/10.1016/j. clay.2003.07.006

37. Groisman L, Rav-Acha C, Gerstl Z and Mingelgrin U. Sorption and Detoxification of Toxic Compounds by a Bifunctional Organoclay. Journal of Environmental Quality. 2004; 33:1930-1936. http:// dx.doi.org/10.2134/jeq2004.1930

38. Lee SY, Kim SJ, Chung SY and Jeong CH. Sorption of hydrophobic organic compounds onto organoclays. Chesmosphere. 2004; 55:781-785. PMid:15013684. http:// dx.doi.org/10.1016/j.chemosphere.2003.11.007

39. Slade PG and Gates WP. The swelling of HDTMA smectites as influenced by their preparation and layer charges. Applied Clay Science. 2004; 25:93-101. http://dx.doi.org/10.1016/j. clay.2003.07.007

40. Yilmaz N and Yapar S. Adsorption properties of tetradecyland hexadecyl trimethylammonium bentonites. Applied Clay Science. 2004; 27:223-228. http://dx.doi.org/10.1016/j. clay.2004.08.001

41. El-Nahhal Y and Safi J. Adsorption of benzene and naphthalene to modified montmorrillionite. Journal of Food, Agriculture and Environmental. 2005; 3(2):295-298.

42. Ramos Vianna MMG, Dweck J, Kozievitc VFJ, Valenzuela-Diaz FR and Büchler PM. Characterization and study of sorptive properties of differently prepared organoclays from a brazilian natural bentonite. Journal of Thermal Analysis and Calorimetry. 2005; 82:595-602. http://dx.doi.org/10.1007/ s10973-005-0939-4

43. Vidal NC and Volzone C. Influencia de la cantidad agregada de Tetrametilamonio a una Bentonita para la Retención de Tolueno. In: Anais do $6^{\circ}$ Encontro Brasileiro sobre Adsorção - EBA; 2006; Maringá. Maringá: Departamento de Engenharia Química Universidade Estatal de Maringá; 2006. CD-ROM. Eixo 1 (23) p. 5. Área Temática 1: Ambiente.

44. Rytwo G, Kohavi Y, Botnick I and Gonen Y. Use of CV- and TPP-montmorillonite for the removal of priority pollutants from water. Applied Clay Science. 2007; 36:182-190. http:// dx.doi.org/10.1016/j.clay.2006.04.016

45. Vidal NC and Volzone C. Captación de metilbenceno por una bentonita argentina modificada con una sal orgánica. Cerámica y Cristal. 2008; 141:90-93.

46. Zhu L and Zhu R. Surface structure of $\mathrm{CTMA}^{+}$modified bentonite and their sorptive characteristics towards organic compounds. Colloids and Surfaces A: Physicochemical and Engineering Aspects. 2008; 320:19-24. http://dx.doi. org/10.1016/j.colsurfa.2008.01.003

47. Vidal NC and Volzone C. Estudio sobre retención de cetiltrimetilamonio por una montmorillonita argentina. In: Anales $8^{\circ}$ EBA - Encuentro Brasileño de Adsorción; 2010; Foz do Iguazú, Brasil. Foz do Iguazú; 2010.

48. Zhang ZZ, Sparks DL and Scrivner NC. Sorption and Desorption of Quaternary Amine Cations on Clays. Environmental Science \& Technology. 1993; 27:1625-1631. http://dx.doi.org/10.1021/ es00045a020

49. Zhu L, Ren X and Yu S. Use of Cetyltrimethylammonium Bromide-Bentonite to Remove Organic Contaminants of Varying Polar Character from Water. Environmental Science \& Technology. 1998; 32:3374-3378. http://dx.doi.org/10.1021/ es980353m

50. Yapar S, Vesile Ö and Zbudak A. Dias Lopes A. Effect of adsorbent concentration to the adsorption of phenol on hexadecyl trimethyl ammonium-bentonite. Journal of Hazardous Materials. 2005; B121:135-139. PMid:15885414. http://dx.doi.org/10.1016/j.jhazmat.2005.01.021

51. Xi Y. Synthesis, characterisation and application of organoclays. [Dissertation]. Queensland: University of Technology, School of Physical and Chemical Sciences, Inorganic Material Research Group, Queensland; 2006.

52. Bergaya F and Lagaly G. Introduction. Surface modification of clay minerals. Applied Clay Science. 2001; 19:1-3. http:// dx.doi.org/10.1016/S0169-1317(01)00063-1

53. Park K-W, Jeong S-Y and Kwon O-Y. Interlamellar silylation of H-kenyaite with 3-aminopropyltriethoxysilane. Applied Clay Science. 2004; 27:21-27. http://dx.doi.org/10.1016/j. clay.2003.12.003

54. Önal M. Examination of Some Commercial Sorptive Organobentonites. Turkish Journal of Chemistry. 2007;31:579-588.

55. Grim ER and Kulbicki G. Montmorillonite: high temperature reactions and classification. The American Mineralogist. 1961; 46:1329-1369.

56. Caballero E, Reyes E, Yusta A, Huertas F and Linares J. Las bentonitas de la zona sur de Cabo de Gata (Almería): Geoquímica y Mineralogía. Acta Geológica Hispánica. 1985; 20(3-4):267-287.

57. Impiccini A and Vallés JM. Los depósitos de bentonita de Barda Negra y cerro Bandera, departamento Zapala, provincia del Neuquén, Argentina. Revista de la Asociación Geológica Argentina. 2002; 57:305-314. 
58. Emmerich K, Wolters F, Kahr G and Lagaly G. Clay profiling: the classification of montmorillonitas. Clays and Clay Minerals. 2009; 57:104-114. http://dx.doi.org/10.1346/ CCMN.2009.0570110

59. Giles $\mathrm{C}-\mathrm{H}$, Smith D and Huitson A. A general treatment and classification of the solute adsorption isotherm. I: Theoretical. Journal of Colloid and Interface Science. 1974; 47:755-765. http://dx.doi.org/10.1016/0021-9797(74)90252-5

60. Eriksson J. Retention and mobilisation of trinitrotoluene, aniline, nitrobenzene and toluene by soil organic matter. [Thesis]. Umea: Sveriges lantbruksuniv, Acta Universitatis agriculturae Sueciae; 2003.

61. Spark D. Environmental Soil Chemistry. 2nd ed. Saint Louis; 2003

62. Zhu R, Zhu L and Xu L. Sorption characteristics of CTMA-bentonite complexes as controlled by surfactant packing density. Colloids and Surfaces A: Physicochemical and Engineering Aspects. 2007; 204:221-227. http://dx.doi. org/10.1016/j.colsurfa.2006.08.016

63. Schwarzenbach RP, Gschwend PM, Imboden DM and Wang LS. Environmental organic chemistry. Beijing: Chemical Industry Press; 2004. 132 p. (in Chinese).

64. Lee SY and Kim SJ. Expansion characteristics of organoclay as a precursor to Nanocomposites. Colloids and Surfaces A: Physicochemical and Engineering Aspects. 2002; 211:19-26. http://dx.doi.org/10.1016/S0927-7757(02)00215-7

65. Volzone C, Rinaldi JO and Ortiga J. Retention of gases by hexadecyltrimethylammonium-montmorillonita clays. Journal of Environmental Management. 2006; 79:247-252. PMid:16182436. http://dx.doi.org/10.1016/j. jenvman.2005.07.004

66. Lagaly G, Fitz S and Weiss A. Kink block structures in clay organic complexes. Clays and Clay Minerals. 1975; 23:45-54. http://dx.doi.org/10.1346/CCMN.1975.0230107

67. Vaia RA, Teukolsky RK and Giannelis EP. Interlayer structure and molecular environment of alkylammonium layered silicates. Chemistry of Materials. 1994; 6:1017-1022. http:// dx.doi.org/10.1021/cm00043a025

68. Zhu J, He H, Guo J, Yang D and Xie X. Arrangement models of alkylammonium cations in the interlayer of $\mathrm{HDTMA}^{+}$pillared montmorillonites. Chinese Science Bulletin. 2003; 48:368-372.

69. Zhu L, Chen B, Tao S and Chiou CT. Interactions of organic contaminants with mineral-adsorbed surfactants. Environmental Science \& Technology. 2003; 37:4001-4006. http://dx.doi.org/10.1021/es026326k

70. Bergaya F, Theng BKG and Lagaly G. Handbook of clay science. Amsterdam: Elsevier; 2006.

71. Zhu R, Zhu L, Xu L and Ruan X. Influence off clay charge densities and surfactant loading amount on the microstructure of CTMA-montmorillonite hybrids. Colloids and Surfaces A: Physicochemical and Engineering Aspects. 2007; 304:41-48. http://dx.doi.org/10.1016/j.colsurfa.2007.04.019

72. Xu L and Zhu L. Structures of OTMA- and DODMA-bentonite and their sorption characteristics towards organic compounds. Journal of Colloid and Interface Science. 2009; 331:8-14. PMid:19081110. http://dx.doi.org/10.1016/j.jcis.2008.11.030

73. Chen B, Zhu L and Zhu J. Configurations of the bentonitesorbed myristylpyridinium cation and their influences on the uptake of organic compounds. Environmental Science \& Technology. 2005; 39:6093-6100. http://dx.doi.org/10.1021/ es0502674

74. Xu S and Boyd SA. Cationic Surfactarrt sorption to a Vermiculite Subsoil via Hydrophobic Boding. Environmental
Science \& Technology. 1995; 29:312-320. http://dx.doi. org/10.1021/es00002a006

75. Xiao W, Zhan M and Li Z. Organically modifying and modeling analysis of montmorillonites. Materials and Design. 2003; 24:455-462. http://dx.doi.org/10.1016/S02613069(03)00064-5

76. He H, Frost RL, Bostrom T, Yuan P, Duong L, Yang D et al. Changes in the morphology of organoclays with HDTMA ${ }^{+}$ surfactant loading. Applied Clay Science. 2006; 31:262-271. http://dx.doi.org/10.1016/j.clay.2005.10.011

77. Wong TC, Wong NB and Tanner PA. A Fourier transform IR study of the phase transitions and molecular order in the hexadecyltrimethylammonium sulfate/ water system. Journal of Colloid and Interface Science. 1997; 186:325-331. PMid:9056361. http://dx.doi.org/10.1006/jcis.1996.4674

78. He H, Frost RL and Zhu J. Infrared study of HDTMA ${ }^{+}$ intercalated montmorillonita. Spectrochimica Acta Part A. 2004; 60:2853-2859. PMid:15350922. http://dx.doi. org/10.1016/j.saa.2003.09.028

79. Zhou Q, Frost R, He H, Xi Y and Liu H. Adsorbed paranitrophenol on HDTMAB organoclay-A TEM and infrared spectroscopic study. Journal of Colloid and Interface Science. 2007; 307:357-363. PMid:17188701. http://dx.doi. org/10.1016/j.jcis.2006.11.047

80. Li Z, Jiang W-T and Hong H. An FTIR investigation of hexadecyltrimethylammonium intercalation into rectorite. Spectrochimica Acta Part A, 2008; 71:1525-1534. PMid:18573686. http://dx.doi.org/10.1016/j.saa.2008.05.015

81. Zhu R, Zhu L, Zhu J and Xu L. Structure of surfactant-clay complexes and their sorptive characteristics toward HOCs. Separation and Purification Technology. 2008; 63:156-162. http://dx.doi.org/10.1016/j.seppur.2008.04.009

82. Kung KS and Hayes KF. Fourier transform infrared spectroscopic study of the adsorption of cetyltrimethylammonium bromide and cetylpyridinium chloride on silica. Langmuir. 1993; 9:163-167. http://dx.doi.org/10.1021/la00025a050

83. Zhu L, Ruan X, Chen B and Zhu R. Efficient removal and mechanisms of water soluble aromatic contaminants by a reducedcharge bentonite modified with benzyltrimethylammonium cation. Chemosphere, 2008; 70:1987-1994. PMid:17983640. http://dx.doi.org/10.1016/j.chemosphere.2007.09.042

84. Silverstein RM and Websterin X. Spectrometric Identification of Organic Compounds. 6th ed. Singapore, Toronto, New York: Chichester Weinheim Brisbane; 1997.

85. Coates J. Interpretation of Infrared Spectra, a Practical Approach. In: Meyers RA, editor. Encyclopedia of Analytical Chemistry. Chichester: John Wiley \& Sons Ltd; 2000. p. 1081510837.

86. Chang M-L, Wu S-C, Chen P-J and Cheng S-C. Infrared investigation of the sequestration of toluene vapor on clay minerals. Environmental Toxicology and Chemistry. 2003; 22(9):1956-1962. PMid:12959520. http:// dx.doi.org/10.1897/02-270

87. Shih Y-H and Wu S-C. Kinetics of toluene sorption and desorption in $\mathrm{Ca}$ - and $\mathrm{Cu}$-montmorillonites investigated with fourier transform infrared spectroscopy under two different levels of humidity. Environmental Toxicology and Chemistry. 2004; 23(9):2061-2067. PMid:15378979. http:// dx.doi.org/10.1897/03-289

88. Amarasinghe PM, Katti KS and Katti D.R. Nature of organic fluid-montmorillonite interactions: An FTIR spectroscopic study. Journal of Colloid and Interface Science. 2009; 337:97-105. PMid:19539947. http://dx.doi. org/10.1016/j.jcis.2009.05.011 
89. Serra RM and Miró EE. Boix AV. FTIR study of toluene adsorption on Cs-exchanged mordenites. Microporous and Mesoporous Materials. 2010; 127:182-189. http://dx.doi. org/10.1016/j.micromeso.2009.07.010

90. Vidal NC. Obtención y caracterización de arcillas orgánicas para su utilización como adsorbentes de tolueno presente en solución acuosa. [Dissertation]. La Plata, Argentina: Facultad de Ingeniería; 2010.
91. Masooleh MS, Bazgir S, Tamizifar M and Nemati A. Adsorption of petroleum hydrocarbons on organoclay. Journal of Applied Chemical Researches. Summer, 2010; 4:1420.

92. Zhu R, Wang T, Zhu J, Ge F, Yuan P and He H. Structural and sorptive characteristics of the cetyltrimethylammonium and polyacrylamide modified bentonite. Chemical Engineering Journal. 2010; 160:220-225. http://dx.doi.org/10.1016/j. cej.2010.03.048 